Tarih Kültür ve Sanat Araştırmaları Dergisi

Revue des Recherches en Histoire Culture et Art

مجلة البحوث التاريخية و الثقافية والفنية
Vol. 6, No. 3, June 2017

Copyright (c) Karabuk University

http://kutaksam.karabuk.edu.tr

\title{
DOI: 10.7596/taksad.v6i3.942
}

Citation: Tosun, C., Yazıcı, H., \& Altun, F. (2017). İlişkide Karar Verme Ölçeğinin Türk Kültürüne Uyarlanmas1. Journal of History Culture and Art Research, 6(3), 650-668. doi:http://dx.doi.org/10.7596/taksad.v6i3.942

\section{İlişkide Karar Verme Ölçeğinin Türk Kültürüne Uyarlanması The Turkish Adaptation of Relationship Deciding Scale}

\section{Cansu Tosun ${ }^{1}$, Hikmet Yazıcı' ${ }^{2}$, Fatma Altun ${ }^{3}$}

\begin{abstract}
The purpose of this study was to assess the validity and reliability of Relationship Deciding Scale (Vennum \& Fincham, 2011) for Turkish culture.

The sample of the study consisted of 880 students (EFA=439, CFA=441) studying at Karadeniz Technical University. Criterion-related validity, exploratory and confirmatory factor analyses were conducted for the validity of RDS while internal consistency, split half and test-retest techniques were performed to examine the reliability of RDS.

Exploratory factor analysis (EFA) revealed that the scale had two-factor structures. However, two items were removed from the scale because they didn't have appropriate factor loadings. The scale consisting of 10 items explained $58.97 \%$ of the total variance. The results of confirmatory factor analysis (CFA) indicated that the model was compatible with the data. In the reliability analysis for EFA and CFA samples, Cronbach alpha coefficients were found as .87 and .86 respectively. Internal consistency coefficients of subscales were found as .83 and .80 for "Relationship Confidence", .82 and .84 for "Directing Relationship". According to test-retest reliability analysis results, the whole scale's coefficient was $r=.67$. In addition, as a result of criterion validity analysis, correlations $(r=.33)$ between Self-Control Scale (Duyan, Gülden \& Gelbal, 2012) and Relationship Deciding Scale (RDS) were found to be statistically significant. In conclusion, these findings suggest that RDS, which has two-factor structures with 10 items, can be suggested as a valid and reliable instrument in Turkish culture.
\end{abstract}

Keywords: Relationship deciding scale, Romantic relationship, Scale adaptation, Validity and Reliability.

\footnotetext{
${ }^{1}$ Arş. Gör., Karadeniz Teknik Üniversitesi, Eğitim Fakültesi, Eğitim Bilimleri Bölümü, Trabzon. E-mail: cansu.tosun@ktu.edu.tr

${ }^{2}$ Prof. Dr., Karadeniz Teknik Üniversitesi, Eğitim Fakültesi, Eğitim Bilimleri Bölümü, Trabzon. E-mail: hyazici@ktu.edu.tr

${ }^{3}$ Yrd. Doç. Dr., Karadeniz Teknik Üniversitesi, Eğitim Fakültesi, Eğitim Bilimleri Bölümü, Trabzon. E-mail: faltun@ktu.edu.tr
} 


\section{Öz}

$\mathrm{Bu}$ araştırmanın amacı, Vennum ve Fincham (2011) tarafından geliştirilen İlişkide Karar Verme Ölçeği’nin (Relationship Deciding Scale) Türk kültürüne uyarlanması ile ilgili geçerlik ve güvenirlik işlemlerini yapmaktır.

Araştırma grubu Karadeniz Teknik Üniversitesi'nde öğrenim gören 880 öğrenciden (AFA=439, DFA=441) oluşmaktadır. İlişkide Karar Verme Ölçeği'nin (İKVÖ) geçerlik işlemlerinde, ölçüt bağıntılı geçerlik, açımlayıcı ve doğrulayıcı faktör analizi, güvenirlik işlemlerinde ise iç tutarlılık, testi yarıya bölme ve testin tekrarı tekniklerinden yararlanılmıştır. Yapılan açımlayıcı faktör analizi (AFA) sonucunda ölçeğin iki faktörlü yapı gösterdiği ortaya çıkmıştır. Uygun faktör yüklerine sahip olmadıkları için iki madde modelden çıkarılmıştır. 10 maddeden oluşan ölçek toplam varyansın \%58.97'sini açıklamıştır. Doğrulayıcı faktör analizli sonuçları (DFA) verinin modele iyi uyum sağladığını göstermiştir. AFA ve DFA örneklemleri için yapılan güvenirlik analizlerinde, Cronbach alfa iç tutarlılık kat sayıları sırasıyla .87 ve .86 olarak bulunurken alt ölçekler için bulunan iç tutarlılık kat sayıları ise "İlişskide Kendine Güven” için .83 ve .80 , “İlişkiyi Yönetme” için .82 ve .84'tür. Ölçeğin test tekrar test güvenirliğinin $r=.67$ olduğu tespit edilmiştir. Ayrıca ölçüt geçerliği kapsamında yapılan analizler sonucunda Öz Denetim Ölçeği (Duyan, Gülden ve Gelbal, 2012) ile İKVÖ arasında .33 değerinde beklenen yönde bir ilişki saptanmıştır. Bu çalışma sonucunda İKVÖ’nün Türk kültüründe geçerli ve güvenilir bir ölçme aracı olduğu değerlendirilmektedir.

Anahtar Kelimeler: İlişkide karar verme, Romantik ilişki, Ölçek uyarlama, Geçerlik ve Güvenirlik.

\section{GIRIŞ}

Karar verme, ortaya çıkan bir ihtiyacı karşılamak amacıyla, ulaşılmak istenen amaçların tespit edilmesini, bunun için gerekli olan bilgilerin toplanarak değerlendirilmesini ve oluşturulacak alternatiflerden en uygun olanının seçilmesini kapsayan davranışsal bir süreçtir (Gürçay, 2001). Bilişsel, duygusal ve davranışsal unsurları hiyerarşik ve ilişkisel bir yapı içinde barındıran bu süreç, önemli birer psikolojik değişken olarak bilinen seçim yapma ve sorumluluk alma işlemleriyle de bağlantılıdır. Bu bakımdan yaşanan olaylar ya da ortaya çıkan durumlar karşısında, bireylerin kişisel donanımlarını hangi güç ve seviyelerde kullanabildikleri ve seçenekler içinde en uygun olanı ne tür değerlendirmeler yoluyla tercih edebilecekleri önemli bir inceleme konusu haline gelmektedir.

Karar verme, başta kişisel ve mesleki olmak üzere, yaşam alanlarıyla ilişkili her tür konu ve sorunları kapsar. Bir tercihte bulunmak gibi basit, kolay ve yüzeysel bir sonuç olarak gözlense 
de, karar verme, bazı psikolojik dinamikleri barındıran ve belli değişkenlerin ilişki ağıyla gerçekleşen karmaşık bir işlem sürecidir. Başta karar vermeyi gerektiren bir güçlügün ortaya çıkması ve bunun birey tarafından hissedilmesi olmak üzere, zorlanmaya yol açan bu güçlüğü gidermeye dönük alternatiflerin gündeme alınıp değerlendirilmesi ve nihai olarak özgürce en uygun seçimin yapılması, karar verme mekanizmalarının basit işlem basamakları olarak değerlendirilebilir (Kuzgun, 2006). Bu aşamaların sağlıklı şekilde geçilmesi, tercih edilen karar verme stratejilerinin nitelikleriyle ilişkilidir. Bireyler tüm seçeneklerin olumlu ya da olumsuz yanlarını değerlendirerek, mantıklı karar verme stratejilerini kullanabilirler. Ya da mevcut seçenekler hakkında etraflıca düşünmeyip tepkisel kararlar alabilirler. Kimileri ise başkasına danışmadan ya da yardım talebinde bulunmadan kararlarını bağımsız şekilde verebilirler. Bazen de memnuniyetsizlik ve kararlarda tutarsızlık şeklinde gözlenen karar verememe veya kararları değiştirme şeklinde bir durum gözlenebilir (Kuzgun, 1992). Yukarıda bahsedilen mantıklı karar verme stratejisinin yanı sıra, bireylerin seçenekleri değerlendirmeden bir seçim yapmaları ya da kararsızlıkları aynı zamanda, bilinçli karar verme becerisinden yoksun olmayı ifade eden savuşturma davranışına da karşılık gelmektedir (Vennum ve Fincham, 2011).

Bazı yaşam olayları karar verme süreçlerini daha duyarlı hale getirir. Evlilik ve evlilik öncesi romantik ilişkiler bu tür hassasiyetlerin gözlendiği kritik yaşam deneyimleridir. Karşılıklı rızaya bağlı olduğu halde, bu tür ilişkilere girmeyi etkileyen içsel ve dışsal kişilik dinamikleri ve aynı zamanda sosyal ya da kültürel bağlamlar mevcuttur. İlişkide karar verme; bireylerin içinde bulundukları romantik ilişkilerde, ilişkinin seyri ve devamı için alınması gereken kararları içermektedir. Cinsel ilişki, birlikte yaşama, evlilik ve hamilelik gibi ilişkinin niteliğini etkileyen önemli geçiş kararlarında bilinçli tercihte bulunmamanın, ilişkinin devamı için ciddi riskler teşkil ettiği bilinmektedir (Stanley, Rhoades ve Markman, 2006). Temel önem ve değere sahip olmakla birlikte ilişki kurma konusunda geliştirilen niyet, karşılıklı rızalık ve irade beyanı, karar verme süreçlerini tek başlarına açıklamada sınırlı kalır.

Araştırmacılar (ör. Avşaroğlu ve Üre 2007; Güçray 2001) insanın benlik bütünlüğü ve kişilik örüntüleriyle ilişkili olan benlik saygısı-öz saygı gibi olumlu değişkenlerin karar verme süreçleri üzerinde anlamlı etkiye sahip olduğunu ortaya koymuşlardır. Benzer çalışmalar atılganlık (Eraslan, 2015), özgüven (Tatlılığlu, 2014) ve duygusal zekânın (Deniz ve Avşaroğlu, 2014) yanında karar verme esnasındaki duygu durumunun da (Arıkan, 2012) karar vermeyle bağlantılı olduğunu göstermektedir. Ayrıca bağlanma stillerinin karar verme sürecinde hem tek başına hem de diğer bazı değişkenlerle etkileşim halinde rol oynadığı belirlenmiştir (Erözkan, 2011). Deniz (2011) öz-sayg1 ve kişilik özelliklerinin bu etkileşime anlamlı katkı sağladığını belirtmiştir. Psikolojik içsel süreçlerin yanında, sosyo-kültürel bazı 
değişkenler de karar verme süreçleri üzerinde etkilidir. Bunlar arasında cinsiyet, sosyoekonomik statü, aile yapısı ve anne-baba tutumları öncelikli bir öneme sahiptir (Tatlılıoğlu, 2014). Eğitim gören gençler arasında bunlara öğrenimle ilgili bazı değişkenler de katılmaktadır (Yüceloğlu-Keskin vd., 2016). Aynı zamanda ergen grupta sosyal destek (Dülger, 2009) ve bununla bağlantılı olarak ana-baba tutumlarının da (Öztürk, Kutlu ve Atlı, 2011) karar verme üzerinde etkili olduğu bilinmektedir.

Evlilik öncesinde önemli bir karar verme aşamasını ifade eden romantik ilişkiler, yukarıda söz konusu edilen tüm psiko-sosyal değişkenlerden etkilenmekle birlikte kendine özgü bazı karar verme temalarını da kapsamaktadır. Savuşturma ya da geçiştirme, birlikteliğe dönük uyarı sinyalleri ve ilişkide güven kavramları bunlardan öne çıkanlardır (Hardy vd., 2015). Bu kavramsal yapılar birer davranışa dönüştüğünde, belli değişkenlerin de etkisiyle kadın ve erkekler arasında tutum ve beceri farklılıklarına yol açmaktadır. Farklı sonuçların özellikle güven ve ilişki memnuniyetini açıklama alanlarında daha belirgin olduğu gözlenmektedir (Owen, Rhoades ve Stanley, 2013; Vennum, Hardy, Sibley ve Fincham, 2015; Yoshida, 2013). Güven ve memnuniyet gibi genel hedefler üzerine inşa edilmeye çalışılan karar verme, süreç olarak ilginç bazı farklılıkları da taşımaktadır. Örneğin bazı çiftler karar verme aşamasından önce etkin bir iletişimi ve karşılıklı tanınmayı ön plana çıkarırken, bazıları bu hususları karar verme aşamasından sonra gündeme getirmektedir (Priem, Bailey ve SteuberFazio, 2015). Sadece bireysel psikoloji yaklaşımı ile açıklanması güç olan bu tercihleri tartışırken, ilişkilere yüklenen toplumsal yüklemelerin göz ardı edilmemesi gerekmektedir.

Karar verme diğer psikolojik değişkenlerden farklı olarak, neredeyse tüm değişkenlerle, içsel ve dışsal süreçlerle, yaşam amaçlarıyla ve farklı konularla ilişkili bir süreçtir. Karar verme konusu ile ilgili olarak Türkiye'de incelemeler ve belli gruplarda farklı ölçek geliştirme ya da uyarlama çalışmaları yapılmıştır (Çolakkadıoğlu, 2012; Çolakkadıŏlu ve Güçray, 2007; Deniz, 2004; Kuzgun, 1992; Taşdelen, 2001).

$\mathrm{Bu}$ çalışma ile önceki araştırmalardan farklı olarak romantik ilişkilerdeki karar verme süreçlerinin incelenmesi planlanmaktadır. Literatür gözden geçirildiğinde Türkiye'de bu hedefe dönük bir ölçek geliştirme ve uyarlama çalışmasına rastlanmamıştır. Oysa toplumda sıklıkla gözlenen romantik ilişkiler, hem psiko-sosyal değişkenlerle hem de evlilik tasarımlarıyla yakından ilgilidir. Bu tür bir ölçme işleminin yapılması, davranış araştırmaları sahasının önemli bir yerini işgal eden çift ve aile konularıyla ilgili birikime bilimsel katkı sağlayabilir. Bu çalışma ile İlişkide Karar Verme Ölçeği'nin Türk kültürüne uyarlanması amaçlanmaktadır. İlişkide Karar Verme Ölçeği bilişsel bir temel üzerine inşa edilmiş kişisel ifadeleri kapsamaktadır. Bu ölçekle romantik ilişkiler için akılcı kararlar verme, çiftlerin 
savuşturma tepkisi gösterme risklerini inceleme ve bunlara belli müdahaleler geliştirme becerilerini inceleme amaç edinilmektedir (Vennum ve Fincham, 2011).

\section{YÖNTEM}

\section{Araştırma Grubu (Katılımcılar)}

Araştırma grubu, Karadeniz Teknik Üniversitesi'nin farklı bölümlerinde öğrenim görmekte olan $880($ Kadın= 555, Erkek $=223$, Belirtilmeyen= 102 $)$ öğrenciden oluşmaktadır. Katılımcılardan toplanan veriler SPSS programı ile rastgele ikiye bölünmüş, kayıp veriler ve uç değerler veri setlerinden çıkartıldıktan sonra iki farklı örneklem grubu oluşturulmuştur. Buna göre, 439 (Kadın= 281, Erkek=114, Belirtilmeyen= 44) kişi üzerinde açımlayıcı faktör analizi (AFA), 441 kişi $(\mathrm{Kad} ı=276$, Erkek=110, Belirtilmeyen= 55) üzerinde doğrulayıcı faktör analizi (DFA) işlemleri yapılmıştır. Yaş aralıkları 17 ile 43 arasında değişen AFA örneklemi için yaş ortalaması 21.77 'dir $( \pm 3.34)$. DFA örneklemindeki öğrencilerin yaşları ise 17 ile 49 arasında değişmekte olup yaş ortalamaları 21.81 'dir ( \pm 3.66$)$. Araştırma grubundaki öğrencilerin çoğunluğu büyük şehirde (\%26.1), şehirde (\%30.1) ve ilçede (\%27.1) ikamet ederken, kasaba (\%3) ve köyde (\%13.3) yaşayanların oranı düşüktür. Çalışma gruplarında yer alanlardan Ayrıca ilişki durumları \%37.6'sının şu sıralarda romantik bir ilişkisi varken, \%62.4'ünün halen ilişkisi bulunmamaktadır.

\section{Araştırmada Kullanılan Veri Toplama Araçları}

\section{Bilgi Toplama Formu}

Katılımcılara ait bazı demografik bilgileri elde etmek amacıyla araştırmacılar tarafından oluşturulmuştur. Bu formda yaş, cinsiyet, romantik ilişki durumu ve ikamet edilen yer ile ilgili sorular yer almaktadır.

\section{İlişkide Karar Verme Ölçeği (Relationship Deciding Scale)}

Romantik ilişkilerde akılcı karar vermeye ilişkin, bireylerin ya da çiftlerin savuşturma davranışı sergileme risklerini tespit ve müdahale etmek için Vennum ve Fincham (2011) tarafından geliştirilmiştir. 12 maddeden oluşan ölçeğin orijinal formunda ilişkide kendine güven, uyarı sinyalleri ve karar verme olmak üzere üç alt boyutu bulunmaktadır. Beşli Likert tipindeki ölçek, kesinlikle katılmıyorum (1) ile kesinlikle katılıyorum (5) arasında değişen bir derecelendirmeye sahiptir. Farklı gruplarda yapılan güvenirlik analizlerinde Cronbach Alfa iç tutarlık katsayısı; "İlişkide Kendine Güven” boyutu için .91 ve .92, “Uyarı Sinyalleri” boyutu 
için .83 ve .87 , "Karar Verme" boyutu için .74 ve .69 olarak belirlenmiştir. On dört hafta ara ile yapılan test tekrar test uygulamasında ölçeğin alt boyutlarına ait korelasyonların .40 ile .51 arasında değiştiği tespit edilmiştir. Üç faktörlü yapı toplam varyansn \%63'nı açıklamaktadır.

\section{Öz-Denetim Ölçeği}

$\mathrm{Bu}$ çalışmada ölçüt geçerliği kapsamında kullanılan Öz-Denetim Ölçeği (Self-Control Schedule), Rosenbaum (1980) tarafından geliştirilip Duyan ve diğerleri (2012) tarafından Türk kültürüne uyarlanmıştır. Ölçek yaşantısal, yenileyici ve onarıcı öz-denetim olmak üzere üç faktörlü bir yapıya sahiptir. Ölçekten alınan puanın artması bireylerin öz-denetim becerilerinin yüksseldiği anlamına gelmektedir. Cronbach Alfa iç tutarlık katsayısı; Yaşantısal Öz-Denetim boyutu için 0.84, Yenileyici Öz-Denetim boyutu için 0.76, Onarıcı Öz-Denetim boyutu için 0.73 ve ölçeğin tamamı için 0.81 olarak belirlenmiştir.

\section{İşlem}

Türk kültürüne uyarlanması planlanan İKVÖ için ölçek sahiplerinden gerekli izinler alınmıştır. İKVÖ’nün dil geçerliği çalışmaları Yabancı Diller Eğitimi bölümü öğretim elemanları ve öğrencileri ile gerçekleştirilmiştir (Dil ve kapsam geçerliliği ile ilgili detaylara bulgular kısmında verilmektedir). Dil geçerliliği tamamlanan ölçeğin öncelikle pilot çalışması yapılmış ve elde edilen analiz sonuçlarına göre bazı maddelerde tekrar dil ve yapı ile ilgili revizyona gidilmiştir.

Ölçme araçlarının son formları oluşturulduktan sonra, ölçekler grup halinde sınıf ortamında ve tek oturumda (ortalama 30 dakikada) uygulanmıştır. Ölçeklerin uygulanması sırasında öğrencilerin araştırmaya katılmaya gönüllü olması esas alınmıştır. Testin tekrarının uygulanacağı gruplarda ölçeğin üzerine rumuz ya da numara yazılması talep edilmiş, diğer katılımcılara ise ölçme araçlarının üzerinde kimliklerini belli edecek herhangi bir işaretleme yapmamaları konusunda hatırlatmada bulunulmuştur.

\section{Veri Analizleri}

Araştırmanın verileri IBM AMOS ve SPSS 23 paket programları ile analiz edilmiştir. Temel istatistiksel tekniklerle gruba ait tanımlayıcı bilgiler ortaya konmuştur. Dil geçerliği kapsamında Türkçe ve İngilizce formlar arasındaki ilişki Spearman Sıra Farkları Korelasyon katsayısı ile incelenmiştir. Ölçme aracının geçerlik işlemleri kapsamında; ölçüt bağıntılı 
geçerlik, açımlayıcı ve doğrulayıcı faktör analizlerinden, güvenirlik analizleri için ise iç tutarlık, testin yarıya bölümü ve testin tekrarı tekniklerinden yararlanılmıştır.

\section{BULGULAR}

\section{İKVÖ’nün Geçerlik Analizleri}

\section{İKVÖ’nün Dil ve Kapsam Geçerliliği}

Ölçeğin Türkçeye çevirisinde ve dilsel eşdeğerliğinin test edilmesinde Hambleton (1996) tarafından önerilen ileri ve geri çeviri yöntemleri olarak bilinen dört basamaklı yaklaşım benimsenmiştir. Bu doğrultuda; ilk olarak ölçeğin orijinal diline ve Türk kültürüne hâkim olan, beş farklı dil uzmanı tarafından ölçek maddeleri Türkçeye çevrilmiştir. İkinci basamakta ise birbirinden bağımsız olarak yapılan bu çeviriler, her iki dile hakim, psikolojik danışma ve ölçme değerlendirme alanlarında uzman 12 araştırmacı tarafından içerik, anlaşılabilirlik, Türk kültürüne ve ölçülmek istenen yapıya uygunlukları değerlendirilmiştir. $\mathrm{Bu}$ doğrultuda oluşturulan Türkçe formun uygun olduğuna dair görüş birliğine varılmıştır.

Üçüncü basamakta, oluşturulan Türkçe form, ölçeğin özgün formunu daha önce görmemiş olan, üç dil uzmanı tarafından İngilizceye geri çevrilmiştir. Bu doğrultuda ortaya çıkan çeviri metni ile ölçeğin orijinal formu arasındaki karşılaştırmalar, her iki dile ve kültüre hâkim olan alan uzmanları ve araştırmacılar tarafindan yapılmıştır. Karşılaştırmalar sonucunda çevirilerin orijinal anlamlarını yansıttığı görülmüştür. Ayrıca bu basamakta, her iki dili iyi bilen 33 kişilik öğrenci grubuna (Yabancı Diller Eğitimi-İngilizce Öğretmenliği bölümü üçüncü sınıf öğrencileri), çalışmanın amacı hakkında bilgi verilerek önce testin orijinal formu, ardından Türkçe formu uygulanmıştır. $\mathrm{Bu}$ aşamada testi cevaplayanlardan anlaşılmayan ifadeleri işaretlemeleri ve önerilerini form üzerinde belirtmeleri istenmiştir. Katılımcıların Türkçe ve İngilizce formlara verdikleri cevaplar arasındaki ilişki Spearman Sıra Farkları Korelasyon katsayısı ile analiz edilmiştir. Türkçe ve İngilizce formların toplam puanları arasındaki korelasyon katsayısının .52 $(\mathrm{p}<.01)$ olduğu gözlenmiştir. Ayrıca uzmanların yanı sıra uygulama yapılan bu gruba da dil geçerliğini sağlama amacı ile maddeleri değerlendirebilmeleri için açık uçlu bir alan verilmiş, uzmanların ve öğrencilerin olumsuz değerlendirme yapmadıkları gözlenmiştir. Önceki basamaklarda yapılan işlemler ve değerlendirmeler göz önünde bulundurularak dördüncü basamakta ölçeğe son hali verilmiştir. 


\section{Pilot Çalışmadan Elde Edilen Bulgular}

Dil geçerliliği tamamlanan formlar, pilot çalışma kapsamında 289 öğrenciye (Kadın= 193, Erkek= 95; Yaş Ort= 19.94 \pm 1.71 ) uygulanmıştır. Bu aşamada ölçeğin güvenirlik ve geçerlikle ilgili bazı değerleri test edilmiştir.

İKVÖ’nün pilot çalışmasında yapılan faktör analizi sonuçları ölçeğin faktörlenebilirliğe uygun olduğunu göstermektedir $\left(\mathrm{KMO}=.77\right.$ ve Barlett $\chi^{2}=949.99$, sd=66, $\left.\mathrm{p}<.05\right)$. Yapılan Temel Bileşenler Analizine göre, öz değeri 1.00'dan büyük dört faktörlü yapının toplam varyansın \%64.98'ini açıkladığı tespit edilmiştir. Ölçeğin bütünü için hesaplanan Cronbach alfa iç tutarlık katsayısı ise .76'dır. Madde toplam korelasyonlarında ise bazı maddelere (m8 ve m12) ait değerlerin .30’un altında olduğu tespit edilmiştir.

$\mathrm{Bu}$ yapıda iki maddenin ( $\mathrm{m} 8$ ve $\mathrm{m} 12$ ) bir faktör oluşturduğu gözlenmiş ve bu durumun uygun görülmemesi sebebiyle (Şencan, 2005) model orijinali ile paralel olarak üç faktörlü bir yapıya zorlanmıştır. Ortaya çıkan yeni yapının toplam varyansın \%55.82'sini açıkladığı belirlenmiştir. Faktörler arasındaki ilişkilerin .32'nin üzerinde olduğu dikkate alınarak (Tabachnic ve Fidell, 2007) Promax rotasyonu uygulanmıştır. Analiz sonucunda bu üç faktörlü yapı içerisinde bazı maddelerin (m1, m6, m7, m11) aynı anda yakın değerlerle birden çok faktöre yüklenmesi durumu ile karşılaşılmıştır. Faktör analizi ve güvenirlik işlemleri sonucunda karşılaşılan bu sorunlar karşısında maddelerin ölçekten çıkarılması tavsiye edilmektedir (Costello ve Osborne, 2005; DeVellis, 2014; Tabachnic ve Fidell, 2007). Fakat pilot niteliğindeki bu çalışmada, maddeler ölçekten çıkarılmadan önce alan uzmanları tarafından dil ve içerik açısından tekrar incelenmiş ve maddeler üzerinde bazı revizyonlar yapılmıştır. Yeniden düzenlenen bu form ile elde edilen veriler üzerinden asıl çalışmalar gerçekleştirilmiştir.

\section{İKVÖ’nün Yapı Geçerliliği}

\section{Açımlayıcı Faktör Analizi (AFA)}

Açımlayıcı faktör analiziyle ilgili işlemlere geçilmeden önce örneklemin normal dağılıma uygun olup olmadığı kontrol edilmiştir. Toplam 439 katılımcının cevapları üzerinde yapılan normallik testi sonucunda çarpıklık ve basıklık katsayılarının (Skewness $=-.64$, Kurtosis= .49) uygun değerler arasında olduğu tespit edilmiştir (Tabachnick, Fiddel ve Osterlind, 2001). Ölçek geliştirme ve uyarlama çalışmalarında önerilen her madde için yaklaşık beş birey oranı (DeVellis, 2014) da dikkate alınarak, AFA örnekleminin yeterli büyüklükte olduğu değerlendirilmiştir. 
İKVÖ’nün yapı geçerliğini test etmek üzere yapılan AFA kapsamında ilk olarak veri setinin faktör analizine uygun olup olmadığını belirlemek için Kaiser-Meyer-Olkin (KMO) örneklem yeterliliği ölçütü ve Barlett's Küresellik testi uygulanmıştır. İKVÖ için KMO değerinin .85, Barlett's küresellik testi sonucu ise anlamlı $\left(\chi^{2}=1932.65, \mathrm{sd}=66, \mathrm{p}<.001\right)$ olduğu görülmektedir. Ayrıca ölçek maddelerinin anti-image matrisindeki çapraz korelasyonları incelenmiş ve .60 ile .92 arasında değişen değerlerin yeterli büyüklükte $(>.50)$ olduğu tespit edilmiştir.

Toplam 12 maddeden oluşan İKVÖ’nün faktör yapısını belirlemek amacıyla Promax döndürme metodu kullanılarak Temel Bileşenler Analizi yapılmıştır. Faktör analizi sonucunda, öz değeri 1.00'dan büyük üç faktörlü bir yapı ortaya çıkmıştır. Toplam varyansın \%61.43'ünü açıklayan bu yapıda 7. maddenin iki faktöre yakın değerlerle (.43 ve .41) yüklendiği, ayrıca 8. ve 12. maddeler ile bir faktör oluşturduğu gözlenmiştir. Fakat 8. ve 12. maddelerin pilot çalışmada olduğu gibi bu çalışmada da .30'un altında (.10 ve .06) maddetoplam korelasyonuna sahip oldukları tespit edilmiştir. $\mathrm{Bu}$ durumda literatürdeki öneriler (Costello ve Osborne, 2005; Tabachnic ve Fidell, 2007), PDR ve ölçme değerlendirme alanlarındaki uzmanlarının görüşleri dikkate alınarak bu iki maddenin analizden çıkarılmasına karar verilmiştir. Elde edilen 10 maddelik form üzerinde faktör analizi işlemleri yeniden yapılmıştır.

İKVÖ’nün 10 maddelik formu için yapılan faktör analizi sonucunda KMO (.86) ve Barlett's değerlerinin $\left(\chi^{2}=1851.67, \mathrm{sd}=45, \mathrm{p}<.001\right)$ uygun olduğu görülmüştür. Promax döndürme metodunun kullanıldı̆̆ 1 Temel Bileşenler Analizi sonucunda, toplam varyansın \%58.97'sini açıklayan iki faktörlü bir yapı elde edilmiştir. Faktör yükleri .52 ile .92 arasında değişen maddelerin hiçbirinin aynı anda birden fazla faktör altında .30'un üzerinde değer göstermedikleri tespit edilmiştir. İlk faktörün açıkladığı toplam varyans \%12.86, ikinci faktörün ise $\% 46.12$ 'dir. Bu durumun; bir faktörün açıkladığı varyansın \%5'ten küçük olmaması (DeVellis, 2014) kuralına da uygun olduğu görülmektedir. Bu doğrultuda bir alt faktörün orijinal ölçekteki madde dağılımının bu çalışma ile birebir uyuştuğu görülmüş ve orijinal formundaki gibi adlandırılmıştır (Relationship Confidence- İlişkide Kendine Güven=m1, m2, m3, m4). Orijinal ölçekte iki boyutta (Uyarı Sinyalleri-Warning Signs- ve Karar Verme -Deciding-) toplanan diğer maddeler ise birleştirilerek yeni bir alt faktör oluşturulmuş ve “İlişkiyi Yönetme” şeklinde isimlendirilmiştir. İKVÖ’nün yapı geçerliliğine ait detaylı bulgular Tablo 1'de özetlenmiştir. 
Faktörler

Maddeler

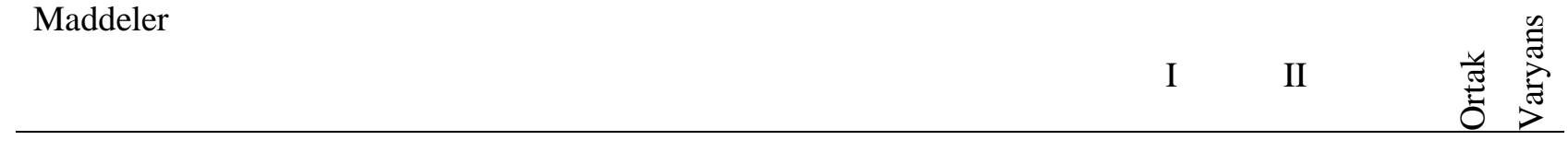

Faktör I. İlişkide Kendine Güven

1.İlişkilerimde ortaya çıkan çatışmalarla etkili bir şekilde baş edebileceğime $\quad .52$ inanırım.

2.Sağlam bir romantik ilişkiye sahip olma konusunda umutluyum.

3.Uzun süreli ve istikrarlı bir ilişkiye sahip olma konusunda kendimden 92 oldukça eminim.

4.Uzun süreli ve istikrarlı bir romantik ilişkiyi sürdürebilmek için gerekli $\quad$ 79 olan becerilere sahibim.

Faktör II. İlişkiyi Yönetme

5.Kötü giden bir ilişkideki tehlike sinyallerini erkenden fark edebilirim.

6.Partnerimle ilişkimde bir sonraki adımı atmadan önce, adımımın artılarını ve eksilerini tartarım (Örneğin; fiziksel yakınlık, evlilik, çocuk sahibi olma).

7.Romantik ilişkilerde önemli adımları atıp atmama konusunda bilinçli kararlar vermek önemlidir.

9.Kötü giden bir ilişkideki tehlike sinyallerini fark ettiğimde ne yapacağımı bilirim.

\section{Faktör $\quad$ 2. Faktör}

Öz değer
Açıklanan Varyans (\%)
12.86
46.12
Toplam $=58.97$ 


\section{Ölçüt Bağıntılı Geçerlik}

Bu çalışmada İKVÖ’nün orijinal çalışmasında da ölçüt geçerliliği için kullanılan ve Türkçe uyarlaması Duyan ve diğerleri (2012) tarafindan yapılan Öz-Denetim Ölçeği kullanılmıştır. Öz-denetim, kişinin kendisi ve dünya arasında daha iyi, daha ideal uyuma sahip olması için kendini değiştirme ve uyarlama kapasitesi olarak değerlendirilmektedir (Duyan vd., 2012). Katılımcıların Öz-Denetim Ölçeği’nden aldıkları puanlar ve İKVÖ'den aldıkları toplam puanlar arasındaki korelasyon $.33(\mathrm{p}<.01)$ olarak tespit edilmiştir. Öz-denetim ile İKVÖ’nün alt boyutları arasındaki ilişkiler ve ölçeğin orijinal çalışmasında yer alan öz-denetim (selfcontrol) ile ölçeğin orijinal formunun alt boyutları arasındaki ilişkiler Tablo 2'de özetlenmiştir.

Tablo 2. İKVÖ ile Öz-Denetim Arasındaki İlişki

\begin{tabular}{|c|c|c|c|c|}
\hline Faktörler & Self-Control & Faktörler & Öz-Denetim & $\mathrm{p}$ \\
\hline Relationship & $.20^{* *}$ & Kendine & $.27^{* *}$ & .00 \\
\hline Confidence $^{\mathrm{a}}$ & & Güven ${ }^{b}$ & & \\
\hline Warning Signs $^{\mathrm{a}}$ & $.23^{* *}$ & İlişkiyi Yönetme ${ }^{b}$ & $.31^{* *}$ & .00 \\
\hline Deciding $^{\mathrm{a}}$ & $.25^{* *}$ & Toplam İKVÖ & $.33^{* *}$ & .00 \\
\hline
\end{tabular}

\section{Doğrulayıcı Faktör Analizi (DFA)}

Toplam 441 katılımcının cevapları üzerinde yapılan normallik testi sonucunda çarpıklık ve basıklık katsayılarının (Skewness = -.79, Kurtosis= 1.10 ) uygun değerler arasında olduğu tespit edilmiştir (Tabachnick vd., 2001). İKVÖ’nün faktör yapısının farklı bir örneklemle ne derece uyum gösterdiğini değerlendirmek amacıyla DFA uygulanmıştır. DFA ile sınanan modelin yeterliğinin belirlenmesinde pek çok uyum iyiliği indeksi vardır. Bunlardan en sık kullanılanlar (Byrne, 2010; Hu ve Bentler, 1999); Ki-kare Uyum Testi (Chi-Square Goodness), Uyum İyiliği İndeksi (Goodness of Fit Index [GFI]), Düzeltilmiş Uyum İyiliği İndeksi (Adjusted Goodness of Fit Index [AGFI]), Karşıllaştırmalı Uyum İndeksi (Comparative Fit Index [CFI]), Yaklaşık Hataların Ortalama Karekökü (Root Mean Square Error of Approximation [RMSEA]) ve Standartlaştırılmış Artık Hataların Ortalama Kareköküdür (Standardized Root Mean Square Residual [SRMR]). Bahsedilen bu değerler 
için belirlenen ölçütler aşağıdaki sunulmuştur. (Bayram, 2013; Byrne, 2010; Doll, Xia ve Torkzadeh, 2011; Hu ve Bentler, 1999):

Tablo 3. Uyum İndeksleri Ölçütleri

\begin{tabular}{lll}
\hline Uyum İndeksleri & Mükemmel Uyum & Kabul Edilebilir Uyum \\
\hline$\chi^{2} \backslash$ sd & $0 \leq \chi^{2} \backslash$ sd $\leq 2$ & $2 \leq \chi^{2} \backslash$ sd $\leq 3$ \\
GFI & $.90 \leq$ GFI $\leq 1.00$ & $85 \leq$ GFI $\leq 90$ \\
AGFI & $.90 \leq$ AGFI $\leq 1.00$ & $80 \leq$ AGFI $\leq 90$ \\
CFI & $.97 \leq$ CFI $\leq 1.00$ & $90 \leq$ CFI $\leq 97$ \\
RMSEA & $0 \leq$ RMSEA $\leq .05$ & $.05 \leq$ RMSEA $\leq .08$ \\
SRMR & $0 \leq$ SRMR $\leq .05$ & $.05 \leq$ SRMR $\leq .10$ \\
\hline
\end{tabular}

$\mathrm{Bu}$ çalışmadaki örneklemde uygulanan AFA sonucunda elde edilen iki faktörlü yapının DFA işlemlerinde tespit edilen uyum iyiliği değerleri ise $\chi^{2} \backslash \mathrm{sd}=5.46\left(\chi^{2}=185.65\right.$, sd $=34, \mathrm{p}<$ $.001), \mathrm{GFI}=.92, \mathrm{AGFI}=.87, \mathrm{CFI}=.91, \mathrm{RMSEA}=.10$ ve SRMR $=.06$ 'dır. Bu sonuçlara ilişkin modifikasyon indeksleri incelendiğinde bazı maddelere ait hata kovaryanslarının modele anlamlı katkı sağlayacağı görülmüştür. Buna göre modele en çok katkı sağlayan modifikasyondan başlanarak 5-10, 9-10 ve 5-9 maddeleri arasında hata kovaryansları tanımlanmıştır. DFA ile tekrar sınanan bu modelin uyum indeksleri ise şu şekilde bulunmuştur; $\chi^{2} \backslash \mathrm{sd}=2.77\left(\chi^{2=} 84.95\right.$, sd $\left.=31, \mathrm{p}<.001\right)$, GFI= .96, AGFI= .94, CFI = .97, $\mathrm{RMSEA}=.06$ ve $\mathrm{SRMR}=.05$.

Tablo 4. İKVÖ DFA Sonuçları

\begin{tabular}{lllll}
\hline $\begin{array}{l}\text { Uyum } \\
\text { İndeksleri }\end{array}$ & Modelin İlk Testi & $\begin{array}{l}\text { 1. Modifikasyon } \\
\text { Sonucu }\end{array}$ & $\begin{array}{l}\text { 2. Modifikasyon } \\
\text { Sonucu }\end{array}$ & $\begin{array}{l}\text { 3. Modifikasyon } \\
\text { Sonucu }\end{array}$ \\
\hline$\chi^{2} \backslash$ sd & 5.46 & 4.05 & 3.15 & 2.77 \\
GFI & .92 & .94 & .96 & .96
\end{tabular}




\begin{tabular}{lcccc} 
AGFI & .87 & .90 & .93 & .94 \\
CFI & .91 & .94 & .96 & .97 \\
RMSEA & .10 & .08 & .07 & .06 \\
SRMR & .06 & .05 & .05 & .05 \\
\hline
\end{tabular}

Bu doğrultuda Türk örnekleminden elde edilen 2 faktör ve 10 maddelik modelin, veri ile iyi uyum gösterdiği söylenebilir. Maddelerin faktörleri ile olan ilişkilerini gösteren standardize edilmiş katsayılar .51 ile .84 arasında değişmekte olup tümü .01 düzeyinde anlamlıdır. Modele ilişkin faktör yükleri Şekil 1'de gösterilmiştir.

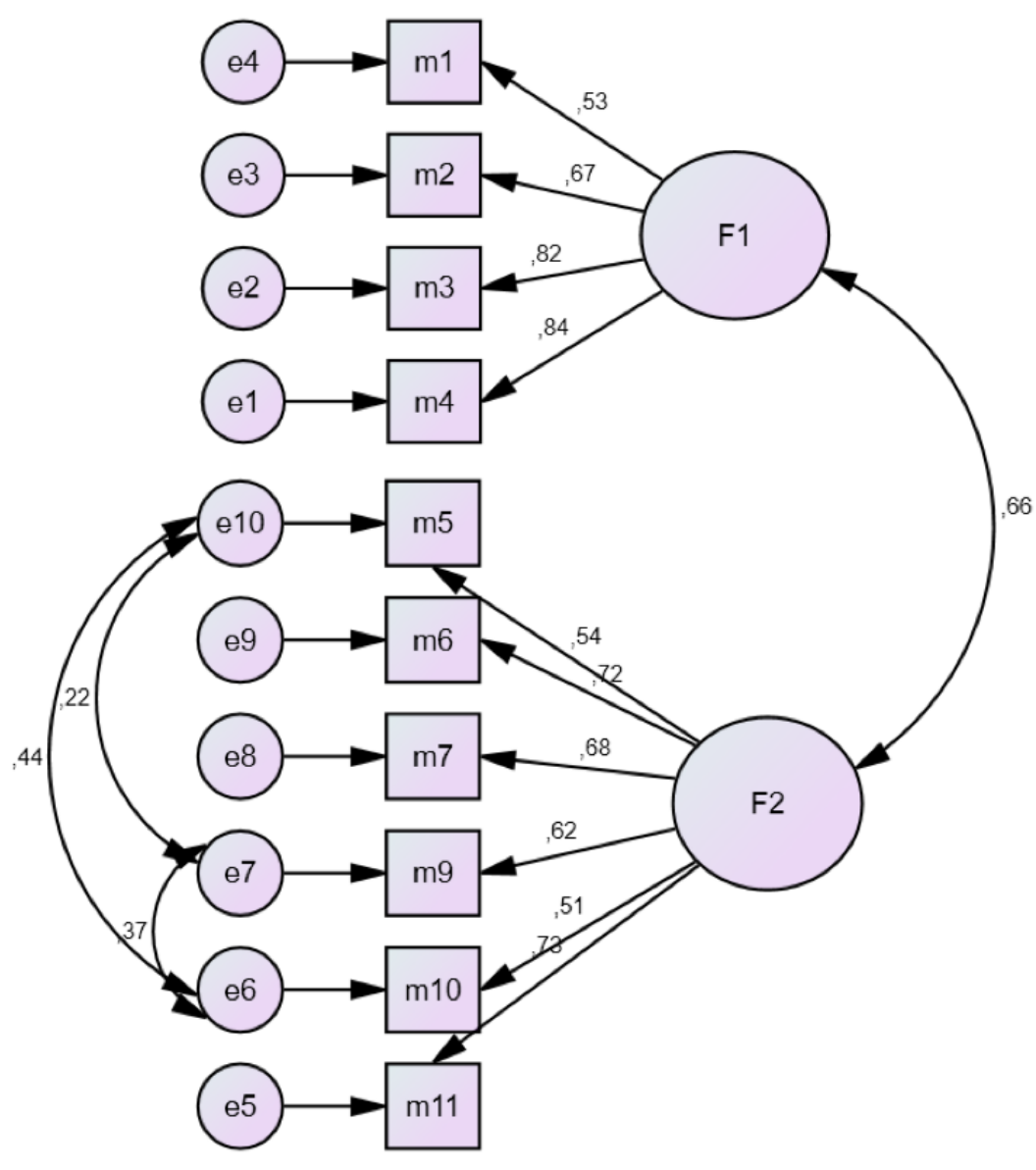

Şekil 1. İKVÖ’ye Yönelik Path Diyagramı ve Faktör Yükleri 


\section{İKVÖ’nün Güvenirlik Analizleri}

İKVÖ’nün güvenirlik analizlerinde Cronbach alfa iç tutarlık katsayısı, testi yarıya bölme ve testin tekrarı yöntemlerinden yararlanılmıştır. Güvenirlik analizinden elde edilen sonuçlar Tablo 5'te özetlenmektedir. Toplam 10 maddeden oluşan ölçeğin iç tutarlığ hem AFA hem DFA yapılan örneklemlerde test edilmiş Cronbach alfa kat sayıları sırasıyla .87 ve .86 olarak bulunmuştur. Alt ölçekler için bulunan Cronbach alfa iç tutarlılık kat sayıları ise "İlişkide Kendine Güven” için .83 ve .80 ve “İlişkiyi Yönetme” için .82 ve .84’tür. İki farklı örneklemde İKVÖ ve alt ölçeklerine uygulanan testi yarıya bölme işlemi sonucunda; tüm ölçek maddeleri için bulunan güvenirlik katsayıları $r=.79$ ve $r=.80$ iken, alt ölçekler için bu değerlerin .85 ve .80 (İlişkide Kendine Güven), .78 ve .84 (İlişkiyi Yönetme) olduğu görülmektedir. AFA analizinde maddelerin madde-toplam korelasyonları .52 ile .70 arasında değişmektedir.

İKVÖ'nün test-tekrar test güvenirlik işlemleri kapsamında ölçek, 60 kişilik bir gruba (44'ü Kadın, 16'sı Erkek, Yaş Ort.= 22.66 \pm 2.52 ) iki hafta arayla tekrar uygulanmış ve sonuçlar Spearman Sıra Farkları Korelasyon katsayısı ile test edilmiştir. Ölçümler sonunda toplam ölçeğin test-tekrar test korelasyonu $.67(\mathrm{p}<.01)$ olarak bulunmuştur.

Tablo 5. İKVÖ’nün Güvenirlik Analizi Sonuçları

\begin{tabular}{|c|c|c|c|c|c|}
\hline Faktör & $\begin{array}{l}\dot{I_{c}} \\
\text { (Cront }\end{array}$ & Tutarlık & $\begin{array}{l}\text { Testi Yartya } \\
\text { (Split Half) }\end{array}$ & Bölme & $\begin{array}{l}\text { Test-Tekrar } \\
\text { Test }\end{array}$ \\
\hline & AFA & A Grubu & AFAGrubu/DF & AGrubu & \\
\hline Toplam İKVÖ & .87 & .86 & .79 & .80 & $.67^{* *}$ \\
\hline İlişkide Kendine Güven ${ }^{\mathrm{a}}$ & .83 & .80 & .85 & .80 & $.58^{* *}$ \\
\hline İlişkiyi Yönetme ${ }^{a}$ & .82 & .84 & .78 & .84 & $.65^{* *}$ \\
\hline
\end{tabular}

\section{TARTIŞMA VE SONUÇ}

$\mathrm{Bu}$ çalışmada, Vennum ve Fincham (2011) tarafından geliştirilen İlişkide Karar Verme Ölçeği'nin (Relationship Deciding Scale) psikometrik özellikleri Türk örneklemi üzerinde 
sınanmıştır. Bu kapsamda İKVÖ’nün yapı geçerliği AFA ve DFA ile test edilmiş, ÖzDenetim Ölçeği (Duyan vd., 2012) ile ölçüt geçerliğine bakılmış, güvenirlik analizlerinde ise iç tutarlılık, testi yarılama ve testin tekrarı yöntemlerinden yararlanılmıştır.

Toplam varyansın \%63'ünü açıklayan orijinal formunun faktör yapısının Türk kültüründe geçerli olup olmadığını test etmek üzere öncelikle açımlayıcı faktör analizi yapılmıştır. Analiz sonucunda öz değeri 1.00'ın üzerinde üç faktörlü bir yapı elde edilmiştir. Fakat bir maddenin çapraz yüklendiği ve diğer iki madde ile bir faktör oluşturduğu gözlenmiştir. Ortaya çıkan faktörün güvenirlik katsayısının $>70$ olduğu (.45), ayrıca çapraz yüklenen 7 . maddenin çıkarılması durumunda iki maddenin (8. ve 12.) bir faktör oluşturduğu gözlenmiştir. $\mathrm{Bu}$ durumun uygun olmaması ve 8 . ile 12. maddelerin madde-toplam korelasyonlarının .30'dan küçük olması sebebiyle PDR ve ölçme alanındaki uzmanların görüşleri dikkate alınarak pilot çalışmada da sorunlu bir yapı gösteren iki madde (8. ve 12.) ölçekten çıkarılmıştır. Üç faktörlü yapı toplam varyansın \%61.43'ünü açıklarken maddelerin atılmasıyla ortaya çıkan iki faktörlü yap1 \%58.97'sini açıklamaktadır. Yine de bu durum Çokluk, Şekercioğlu ve Büyüköztürk (2012) tarafından belirtildiği üzere sosyal bilimler için geliştirilen ölçme araçları için yeterlidir.

Çıkarılan maddelere bakıldığında ikisinin de ters kodlandı̆̆ 1 ve benzer içeriğe sahip oldukları gözlenmektedir: 8. madde "Romantik bir ilişkideki her önemli adımın artılarını ve eksilerini düşünmek ilişkisinin doğasına zarar verir" şeklinde iken, 12. madde "Romantik ilişkilerde atılacak her önemli adımı dikkatle düşünmektense 'akışına bırakmak' daha iyidir” şeklindedir. Bu iki maddenin ölçmeye çalıştığı durumun daha önce beraber bir faktör oluşturdukları 7 . madde de olumlu ifade edildiği görülmektedir "Romantik ilişkilerde önemli adımları atıp atmama konusunda bilinçli kararlar vermek önemlidir”, bu doğrultuda istenilen kavramın ölçülmesinde geride kalan 7. maddenin yeterli olacağı düşünülmektedir. Ayrıca iki maddenin çıkarılması ile birlikte güvenirlik kat sayısının .82'den .87 'e yükselmesi maddelerin çıkarılmasının anlamlı olduğunu göstermektedir.

AFA sonucunda 10 maddelik formda orijinal formdaki bir faktör (ilişkide kendine güven) aynı şekilde korunmuş, diğer iki faktör (uyarı sinyalleri ve karar verme) ise bir faktörde (ilişkiyi yönetme) toplanmıştır. Orijinal ölçekteki uyarı sinyalleri faktörü, bireylerin ilişkide yer alan tehlikeli durumları görebilmelerini barındırırken, karar verme boyutu ise ilişkilerde önemli olduğu düşünülen noktalardaki karar verme süreçlerini ve tutumlarını ifade etmektedir. Oluşan iki faktörlü yapıdaysa belirtilen faktörlerin birleştirilmesi ile oluşan faktörün; ilişkideki tehlikeli durumlarının fark edilmesi, bu durumlarda ne yapılacağının bilinmesi ve ilişkideki dönüm noktaları ile ilgili kararların verilmesini içerdiğinden "İlişkiyi Yönetme" olarak adlandırılması uygun görülmüştür. 
İKVÖ için yapılan DFA sonuçlarına göre elde edilen değerler, ; $\chi^{2} \backslash \mathrm{sd}=2.77(\chi 2=84.95$, sd= $31, \mathrm{p}<.001), \mathrm{GFI}=.96, \mathrm{AGFI}=.94, \mathrm{CFI}=.97, \mathrm{RMSEA}=.06$ ve $\mathrm{SRMR}=.05$. olarak tespit edilmiştir. Bu doğrultuda, Türk örnekleminden elde edilen 2 faktör ve 10 maddelik modelin, veri ile iyi uyum gösterdiği söylenebilir. $\mathrm{Bu}$ değerlerin ölçeğin orijinal çalışmasındaki (Vennum ve Fincham, 2011) DFA sonucunda elde edilen uyum indekslerinden $\left(\chi^{2}(51)=354.49, \mathrm{CFI}=.95, \mathrm{RMSEA}=.08\right.$ ve $\left.\mathrm{SRMR}=.05\right)$ daha iyi değerlere sahip olduğu gözlenmektedir.

Ölçeğin Öz-Denetim Ölçeği ile arasındaki korelasyon $r=.33(\mathrm{p}<.01)$ olarak tespit edilmiştir. Orijinal formun alt boyutları ile öz-denetim arasında bulunan korelasyonların benzer olduğu (.20 ile .25 arasında değişmektedir) gözlenmiştir.

Güvenirlik analizleri kapsamında yapılan iç tutarlılık testi sonucunda iki ayrı örneklem için bulunan Cronbach alfa kat sayıları sırasıyla .87 ve .86 'dır. Ölçeğin Türkçe formuna ait alt faktörler için tespit edilen iç tutarlılık kat sayıları "İlişkide Kendine Güven” için .83 ve .80 ve “İlişkiyi Yönetme” için .82 ve .84'tür. Bu sonuçlar ölçeğin güvenirlik değerlerinin kabul edilebilir düzeyde yüksek olduğunu göstermektedir (Şencan, 2005). Ölçümler sonunda toplam ölçeğin test-tekrar test korelasyonu $.67(\mathrm{p}<.01)$ olarak bulunmuştur. Orijinal çalışmada ise alt faktörlere ait test tekrar test korelasyonlarının .40 ile .51 arasında değiștiği, bu doğrultuda Türkçe formun daha iyi değerlere sahip olduğu gözlenmektedir.

Bilinçli karar verme eksikliği olarak tanımlanan savuşturma (Vennum ve Fincham, 2011) ilişkinin seyri için olumsuz sonuçlar ortaya çıkarabilmektedir. İlişkide Karar Verme Ölçeği bireylerin romantik ilişkide bireylerin ya da çiftlerin savuşturma davranışı sergileme risklerini tespit ve müdahale etmek amacı ile geliştirilmiştir. Bu araştırmanın bulguları 1şığında ise İKVÖ’nün Türk kültüründe geçerli ve güvenilir bir ölçme aracı olarak kullanılabileceği sonucuna ulaşılmıştır. Diğer taraftan bu çalışmada yalnızca belirli bir sosyo-ekonomik gelir düzeyine sahip üniversite öğrencilerinden veri toplanması bir sınırlılık olarak görülmektedir. Bu kapsamda farklı eğitim seviyelerinden, sosyo-ekonomik sınıflardan ve yaşam döngüsünde daha ileri düzeyde bulunan bireyler üzerinde ölçeğin psikometrik işlemlerinin tekrar edilmesi önerilmektedir. Ayrıca Türk kültürüne uygunluk gösteren farklı maddelerin de ölçeğe eklenmesinin Türk kültüründeki romantik ilişkilerdeki karar verme süreçlerinin anlaşılması ile ilgili araştırmalara anlamlı katkı sağlayacağı düşünülmektedir. 


\section{Kaynakça / References}

Arıkan, E. (2012). Karar verme süreçlerinde duygunun rolü. Yayınlanmamış yüksek lisans tezi, Ege Üniversitesi, İzmir.

Avşaroğlu, S. \& Üre, Ö. (2007). Üniversite öğrencilerinin karar vermede özsayg1, karar verme ve stresle başaçıkma stillerinin benlik saygısı ve bazı değişkenler açısından incelenmesi. Selçuk Üniversitesi Sosyal Bilimler Enstitüsü Dergisi, 18, 85-100.

Bayram, N. (2013).Yapısal Eşitlik Modellemesine giriş: AMOS uygulamaları (2. baskı), İstanbul: Ezgi Kitabevi.

Byrne, B. M. (2010).Structural Equation Modeling with AMOS: Basic concepts, applications, and programming (2nd ed.). New York: Routledge.

Costello, A. B. \& Osborne, J. W. (2005). Best practices in Exploratory Factor Analysis: Four recommendations for getting the most from your analysis. Practical Assessment, Research and Evolotion, 10(7): 1-9.

Çokluk, Ö.; Şekercioğlu, G. \& Büyüköztürk, Ş. (2012). Sosyal bilimler için çok değişkenli istatistik: SPSS ve Lisrel uygulamaları. Ankara: Pegem Akademi Yayıncılık.

Çolakkadıoğlu, O. (2012). Ergenlerde Karar Verme Ölçeği'nin ortaöğretim öğrencileri için geçerlik ve güvenirlik çalışması. Mustafa Kemal Üniversitesi Sosyal Bilimler Enstitüsü Dergisi, 9(19), 387-403.

Çolakkadıoğlu, O. \& Güçray, S. S. (2007). Ergenlerde Karar Verme Ölçeği'ni Türkçe‘ye uyarlama çalışmas1. Eurasian Journal of Educational Research (EJER), 26, 61-71.

Deniz, M. E. (2004). "Investigation of the relation between decision making self-esteem, decision making style and problem solving skills of university students”. Eurasian Journal of Educational Research, 15, 23-35.

Deniz, E. (2011). Karar verme stilleri ve beş faktör kişilik özelliklerinin bağlanma stilleri açısından incelenmesi. Kuram ve Uygulamada Eğitim Bilimleri, 11(1), 97-113.

Deniz, M. \& Avşaroğlu, S. (2014). Üniversite Öğrencilerinin Duygusal Zekâ Yeteneklerinin Karar Vermede Özsaygı ve Karar Verme Stillerini Açıklama Düzeyinin İncelenmesi. Ë̈ Eğitim Fakültesi Dergisi, 16(1), 121-138.

DeVellis, R. F. (2014).Ölçek geliştirme kuram ve uygulamalar. T. Totan (Çev. ed. 3. basımdan çeviri). Ankara: Nobel.

Doll, W. J.; Xia, W. \& Torkzadeh, G. (1994).A confirmatory factor analysis of the end-user computing satisfaction instrument. Mis Quarterly, 18(4): 453-461.

Duyan, V.; Gülden, Ç. \& Gelbal, S. (2012). Öz-Denetim Ölçeği: Güvenirlik ve Geçerlik Çalışması. Toplum ve Sosyal Hizmetler, 23(1), 25-38.

Dülger, Ö. (2009). Ergenlerde algılanan sosyal destek ile karar verme davranışları arasındaki ilişkinin incelenmesi. Yayınlanmamış Yüksek Lisans Tezi, Marmara Üniversitesi, İstanbul.

Eraslan, M. (2015). Üniversite spor bölümü öğrencilerinin atılganlık ve karar verme stillerinin çeşitli değişkenlere göre incelenmesi. Bartın Üniversitesi Ĕ̆itim Fakültesi Dergisi, 4(1), 214-223. 
Erözkan, A. (2011). Üniversite Öğrencilerinin Bağlanma Stilleri ve Karar Stratejileri. Uluslararası Avrasya Sosyal Bilimler Dergisi, 2(3), 60-74.

Güçray, S. S. (2001). Ergenlerde karar verme davranışlarının öz saygı ve problem çözme becerileri algısı ile ilişkisi. Çukurova Üniversitesi Sosyal Bilimler Enstitüsü Dergisi, 8(8), 106-121.

Hambleton, R. K. (1996) Guidelines for adapting educational and psychological tests. Annual Meeting of the National Council on Measurement in Education. New York: US Educational Resources Information Center.

Hardy, N. R.; Vennum, A.; Johnson, M. D.; Anderson, J. R.; Luu, S. \& Liu, W. (2015). Associations between attention to warning signs, marital confidence, and interactional problem solving among emerging adult couples in Mainland China. Emerging Adulthood, 3(3), 194-203.

Hu, L. T. \& Bentler, P. M. (1999). Cutoff criteria for fit indexes in covariance structure analysis: Conventional criteria versus new alternatives. Structural Equation Modeling: A Multidisciplinary Journal, 6(1), 1-55.

Kuzgun, Y. (1992). Karar stratejileri ölçeği: Geliştirilmesi ve standardizasyonu. VII. ulusal psikoloji kongresi bilimsel çalışmaları. Ankara: Türk Psikologlar Derneği.

Kuzgun, Y. (2006). Meslek gelişimi ve danışmanlığı (2. Baskı). Ankara: Nobel Yayın Dağıtım.

Owen, J.; Rhoades, G. K. \& Stanley, S. M. (2013). Sliding versus deciding in relationships: Associations with relationship quality, commitment, and infidelity. Journal of Couple \& Relationship Therapy, 12(2), 135-149.

Öztürk, N.; Kutlu, M. \& Atl1, A. (2011). The effect of parents' attitudes on adolescents' decisionmaking strategies. Inonu University Journal of the Faculty of Education (INUJFE), 12(2), 45-64.

Priem, J. S.; Bailey, L. C. \& Steuber Fazio, K.. (2015). Sliding versus deciding: A theme analysis of deciding conversations of non-engaged cohabiting couples. Communication Quarterly, 63(5), 533549.

Stanley, S. M.; Rhoades, G. K. \& Markman, H. J. (2006). Sliding versus deciding: Inertia and the premarital cohabitation effect. Family Relations, 55, 499-509.

Şencan, H. (2005). Sosyal ve davranışsal ölçümlerde güvenirlik ve geçerlik. Ankara: Seçkin Yayınc1lık.

Tabachnick, B.G. \& Fidell, L. S. (2007).Using multivariate statistics (5th ed.). Upper Saddle River, NJ: Pearson Allyn \& Bacon.

Tabachnick, B. G.; Fidell, L.S. \& Osterlind, S. C. (2001). Using multivariate statstics. Boston: Allyn and Bacon.

Taşdelen, A. (2001). Öğretmen adaylarının bazı psiko sosyal değişkenlere göre karar verme stilleri. Pamukkale Üniversitesi Eğitim Fakültesi Dergisi, 10(10), 40-52.

Tatlılığlu, K. (2014). Üniversite öğrencilerinin karar vermede öz-saygı düzeyleri ile karar verme stilleri arasındaki ilişkinin bazı değiş̧kenlere göre incelenmesi. Akademik Sosyal Araştırmalar Dergisi, 2(1), 150-170.

Vennum, A. \& Fincham, F. D. (2011). Assessing decision making in young adult romantic relationships. Psychological Assessment, 23(3), 739. 
Vennum, A.; Hardy, N.; Sibley, D. S. \& Fincham, F. D. (2015). Dedication and sliding in emerging adult cyclical and non-cyclical romantic relationships. Family Relations, 64(3), 407-419.

Yoshida, E. M. Understanding how deciding and relationship confidence predict relationship satisfaction. CMC Senior Theses.

Yüceloğlu-Keskin, D. Ö.; Bayram, L.; Günay-Derebaşı, D.; Bostanc1, Ö. \& Kabadayı, M. (2016). Üniversite Öğrencilerinin Kullandıkları Karar Verme Stratejilerinin Bazı Demografik Değişkenlere Göre İncelenmesi. Gaziantep Üniversitesi Spor Bilimleri Dergisi, 1(2), 1-12. 